\title{
Properties of Thyrotropin (TSH) Binding to Plasma Membranes Prepared from Rat Fat Tissues
}

\author{
Kazuro Kaise, Nobuko Kaise, Katsumi Yoshida, \\ Yoichi Itagaki, Yoshinori Kiso, Tsunehiro Arai, \\ Makiko Yamamoto, Toshiro Sakurada, Shintaro Saito \\ and Kaoru Yoshinaga
}

The Second Department of Internal Medicine, Tohoku University School of Medicine, Sendai 980

Kaise, K., Kaise, N., Yoshida, K., Itagaki, Y., Kiso, Y., Arai, T., Yamamoto, M., Sakurada, T., Saito, S. and Yoshinaga, K. Properties of Thyrotropin (TSH) Binding to Plasma Membranes Prepared from Rat Fat Tissues. Tohoku J. exp. Med., 1988, 154 (2), 115-124 — Rat fat membranes were prepared from male Sprague-Dawley rats. At $37^{\circ} \mathrm{C}$, TSH binding to rat fat membranes was rapid and unstable, although the binding reached a steady state after $2 \mathrm{hr}$ and unchanged up to $24 \mathrm{hr}$ at $4^{\circ} \mathrm{C}$. The binding to rat fat membranes was significantly inhibited by $50 \mathrm{mM} \mathrm{NaCl}$ and almost completely inhibited by $150 \mathrm{mM} \mathrm{NaCl}$. TSH binding to rat fat membranes was not affected by $10 \mathrm{mM}$ dithiothreitol (DTT) or $1 \mathrm{mM}$ diamide although the binding to human thyroid membranes was inhibited by $10 \mathrm{mM}$ DTT significantly. Conventional Scatchard analysis revealed a single class of binding site which had lower $\mathrm{K}_{\mathrm{a}}$ value $\left(2.6 \times 10^{8} \mathrm{M}^{-1}\right)$ than that of high affinity binding site of human thyroid membranes $\left(9.3 \times 10^{8} \mathrm{M}^{-1}\right)$. Immunoglobulin G (IgG) from patients with Graves' disease inhibited the binding of TSH to rat fat membranes. A significant correlation was observed between the inhibiting activity of Graves' IgG measured with rat fat and human thyroid membranes $(r=0.82$, $p<0.01)$. In conclusion, TSH receptors on rat fat menbranes were not identical to those on human thyroid membranes, but TSH receptor antibodies crossreacted with TSH receptors in rat fat tissue. —_ thyrotropin receptor; rat fat membrane ; Graves' disease

Several reports have indicated the presence of thyrotropin (TSH) receptors in fat tissues (Teng et al. 1975; Davies et al. 1978; Gill et al. 1978a, b; Trokoudes et al. 1979 ; Kishihara et al. 1979a, b, 1981). TSH receptors on thyroid membranes appear to be important in the pathogenesis of Graves' disease, since sera of these patients contain antibodies which interact with TSH recepors and may cause hyperthyroidism (Smith and Hall 1974; Smith et al. 1985). These antibodies also inhibit TSH binding to fat cell membranes (Teng et al. 1975 ; Kishihara et al. 1979a, 1981). Recent reports have demonstrated that antibodies in the serum of patients with Graves' disease appeared to bind to membranes with TSH

Received September 25, 1987 ; revision accepted for publication January 19, 1988. 
receptors (Tao and Kriss 1982 ; Baker et al. 1983). It is beneficial to use fat cell membranes to detect these antibodies owing to the lack of confusion caused by the presence of antithyroid antibodies other than TSH receptor antibodies (TRAb). Properties of TSH binding to guinea pig fat membranes have been reported in detail from other laboratories (Teng et al. 1975; Gill et al. 1978a, b ; Kishihara et al. 1979a, b, 1981). TSH binding to human fat membranes was reported to be highly sensitive to normal immunoglobulin G ( $\operatorname{IgG}$ ) (Gill et al. 1980). However, few studies about TSH binding to rat fat membranes were reported (Gill et al. 1978a). Kishihara et al. (1979a) reported that TSH receptors could not be detected on rat fat membranes. In the present report, the presence of TSH receptors on rat fat membranes was confirmed, and their interaction with TSH and Graves' IgG was compared with that of human thyroid membranes.

\section{Materials and Methods}

\section{Preparation of rat fat and human thyroid membrane}

Rat fat membranes were prepared from the epididymal fat pads and perinephric fat tissues of male Sprague-Dawley rats using the method of Teng et al. (1975) with minor modifications. Briefly, fat tissues were razor-minced and homogenized by a Polytron homogenizer in 10 volumes of homogenizing buffer $(250 \mathrm{mM}$ sucrose, $1 \mathrm{mM}$ EDTA, $20 \mathrm{mM}$ Tris-HCl, $\mathrm{pH}$ 7.4). A particulate fraction containing plasma membranes (800 to $10,000 \times$ g) obtained from $1 \mathrm{~g}$ wet tissue was suspended in $0.2 \mathrm{ml}$ of $20 \mathrm{mM}$ Tris-HCl at $\mathrm{pH} 7.4$ containing $1 \mathrm{mM} \mathrm{EDTA}$, and stored at $-80^{\circ} \mathrm{C}$.

Human thyroid membranes, obtained from $1 \mathrm{~g}$ wet tissue of Graves' thyroid and prepared as described above, were suspended in $1 \mathrm{ml}$ of the buffer and stored at $-80^{\circ} \mathrm{C}$ until use.

\section{Iodination of bTSH}

Highly purified bovine TSH (bTSH) (generous gift from Dr. J.G. Pierce, UCLA, Los Angles, CA, USA and Dr. N. Ui, Gunma University, Maebashi) was labeled with ${ }^{125}$ ( New England Nuclear Corp., Boston, MA, USA) by the lactoperoxidase method to yield a specific activity of 50 to $80 \mu \mathrm{Ci} / \mu \mathrm{g}$. Then labeled TSH was purified using human thyroid membranes and sephadex G100 column chromatography according to the method of Smith and Hall (1974). The bindings of these two purified bTSH preparations to human thyroid membranes were almost identical (data were not shown).

\section{Preparation of $I g G$}

Serum IgG fractions were prepared from sera of 12 patients with Graves' disease and 3 normal subjects by precipitation with ammonium sulfate (a final concentration of $1.6 \mathrm{M}$ ). The fractions were dissolved in distilled water, dialyzed against $50 \mathrm{mM} \mathrm{NaCl}, 10 \mathrm{mM}$ Tris- $\mathrm{HCl}, \mathrm{pH} 7.4$, at $4^{\circ} \mathrm{C}$ for $24 \mathrm{hr}$, adjusted to the concentration of $10 \mathrm{mg} / \mathrm{ml}$, and stored at $-20^{\circ} \mathrm{C}$. Protein concentrations were determined by the method of Lowry et al. (1951) using bovine serum albumin as the standard.

\section{bTSH binding assay}

Standard binding conditions were as follows. Rat fat membranes in $50 \mu$ l buffer were incubated with unlabeled bTSH (Thytropar ${ }^{\circledR}$, Armour Pharmaceutical Co., Chicago, IL, USA) or Graves' IgG in $100 \mu \mathrm{l}$ of assay buffer ( $50 \mathrm{mM} \mathrm{NaCl}, 0.1 \% \mathrm{BSA}, 10 \mathrm{mM}$ Tris-HCl, $\mathrm{pH} 7.4)$ at $37^{\circ} \mathrm{C}$ for $10 \mathrm{~min}$. Then $100 \mu \mathrm{l}$ of labeled TSH $(10,000 \mathrm{cpm})$ was added and the incubation was continued at $4{ }^{\circ} \mathrm{C}$ for further $2 \mathrm{hr}$. Fat membranes were sedimented by a 
Beckmann Microfuge at $10,000 \times \mathrm{g}$ at $4^{\circ} \mathrm{C}$ for $5 \mathrm{~min}$ and the radioactivity of the pellets was counted with a gamma counter (Model AL-201, Shimadzu Seisakusho LTD, Tokyo). Results were corrected by subtracting the nonspecific binding. The binding studies of human thyroid membranes were carried out as previously described by Smith and Hall (1974). Fat membranes were present at the concentration of 22 to $30 \mu \mathrm{g}$ protein/tube, and human thyroid membranes were present at the concentration of 70 to $100 \mu \mathrm{g}$ protein/tube. The effects of sulfhydryl (SH) reagents on TSH binding to rat fat membranes were examined as follows. Rat fat or human thyroid membranes were incubated with $10 \mathrm{mM}$ dithiotheitol (DTT) or $1 \mathrm{mM}$ azodicarboxylic acid-bis-dimethylamide (diamide) at $37^{\circ} \mathrm{C}$ for $45 \mathrm{~min}$ and washed two times with incubation buffer. Then standard binding assay was carried out. The effect of IgG from the patients with Graves' disease on TSH bindinbg to rat fat and human thyroid membranes was expressed as thyrotropin binding inhibitor immunoglobulin (TBII) index [TBII index $(\%)=$ (specific binding of labeled TSH in the presence of patient's IgG/specific binding of labeled TSH in the presence of control $\operatorname{IgG}) \times 100]$.

\section{Statistical analysis}

Statistical analysis was done by Student's $t$-test.

\section{RESUlts}

The time course of TSH binding to rat fat membranes is shown in Fig. 1. At $37^{\circ} \mathrm{C}$, its binding was rapid, reaching the maximal level in $15 \mathrm{~min}$, followed by a marked fall during the next $2 \mathrm{hr}$. At $4^{\circ} \mathrm{C}$, the binding was slow, but reached a steady state after $2 \mathrm{hr}$ and remained unchanged up to $24 \mathrm{hr}$. The incubation of labeled TSH in subsequent experiments was therefore carried out for $2 \mathrm{hr}$ at $4^{\circ} \mathrm{C}$. In the absence of unlabeled TSH, incubation time before the addition of labeled

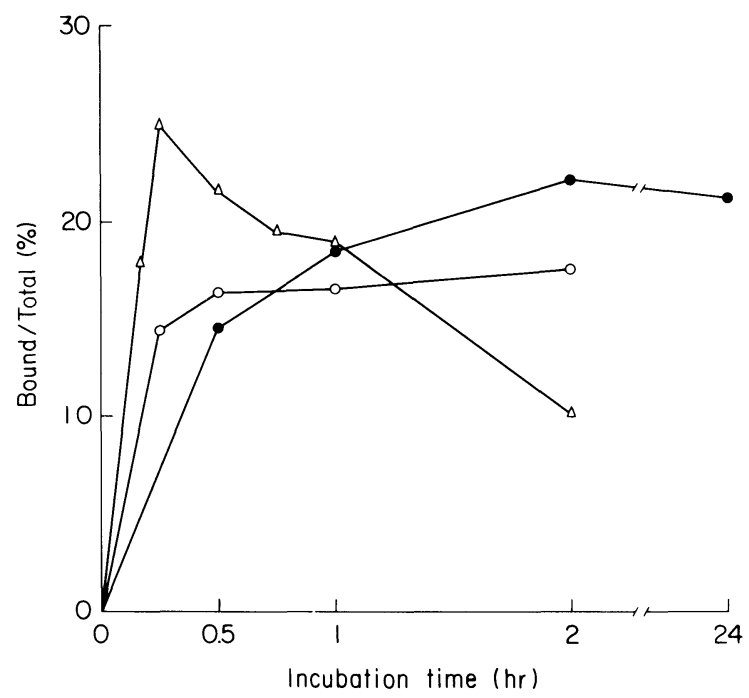

Fig. 1. Effect of time and temperature on labeled TSH binding to rat fat and human thyroid membranes. Rat fat membranes were incubated with labeled $\mathrm{TSH}$ at $4^{\circ} \mathrm{C}(\bullet)$ or $37^{\circ} \mathrm{C}(\triangle)$.

Human thyroid membranes $(\supset)$ were incubated with labeled TSH at $37^{\circ} \mathrm{C}$. Each point represents the mean of duplicate determinations. 
TSH was prolonged up to $45 \mathrm{~min}$ at $37^{\circ} \mathrm{C}$, but no reduction of the binding was observed. Labeled TSH binding to human thyroid membranes reached the maximal level in $30 \mathrm{~min}$ at $37^{\circ} \mathrm{C}$ and unchanged for $2 \mathrm{hr}$. Specific binding to rat fat membranes was 25 to $31 \%$ and that to human thyroid membranes was 14 to $24 \%$.

The concentration of $50 \mathrm{mM}$ of $\mathrm{NaCl}$ significantly inhibited the specific binding to rat fat membranes whereas the same concentration of $\mathrm{NaCl}$ did not inhibit the binding to human thyroid membranes (Fig. 2). TSH binding to rat fat membranes was almost completely inhibited by $150 \mathrm{mM} \mathrm{NaCl}$ although the binding to human thyroid membranes was reduced by $40 \%$.

TSH binding to rat fat membranes was not affected by $\mathrm{SH}$ reagents although the binding to the thyroid membranes was affected significantly by $10^{-2} \mathrm{M}$ DTT

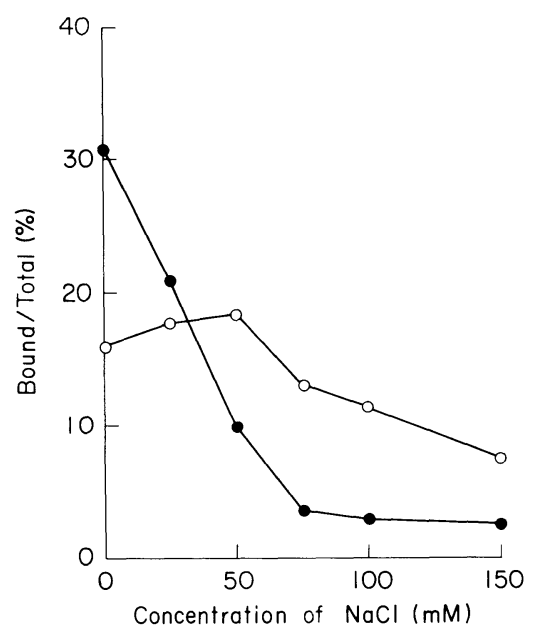

Fig. 2. Effect of $\mathrm{NaCl}$ concentrations on labeled TSH binding to rat fat and human thyroid membranes. Rat fat membranes (•) were incubated with labeled TSH at $4^{\circ} \mathrm{C}$ for $2 \mathrm{hr}$ and human thyroid membranes $(\odot)$ were incubated with labeled TSH at $37^{\circ} \mathrm{C}$ for an hour. Each point represents the mean of duplicate determinations.

TABLE 1. Effect of SH reagents on TSH binding to rat fat and human thyroid membranes

Labeled TSH binding $(\%)$

\begin{tabular}{lcc}
\cline { 2 - 3 } & Rat fat membrane & Human thyroid membrane \\
\hline $10^{-3}$ M diamide & $18.3 \pm 0.65$ & $17.6 \pm 0.35$ \\
$10^{-2}$ M DTT & $18.2 \pm 0.60$ & $6.9 \pm 0.41^{* *}$ \\
Control & $18.2 \pm 0.35$ & $17.1 \pm 0.55$ \\
\hline
\end{tabular}

Each value is mean \pm S.D. of triplicate determinations.

${ }^{* *} p<0.01$ against values in control. 


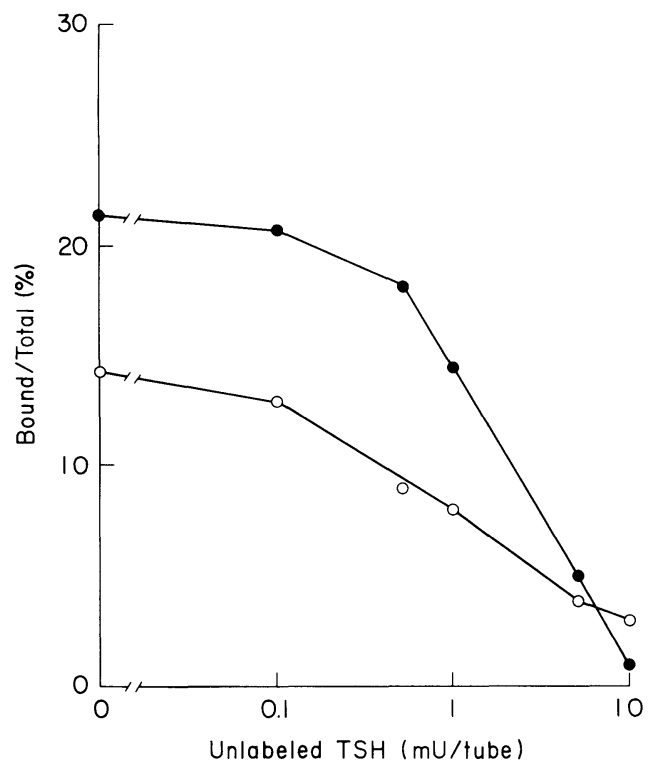

Fig. 3. Displacement curve of labeled TSH from rat fat (•) and human thyroid ( ) membranes by unlabeled TSH. The results shown are representative of an experiment among those performed five or four times. Each point is the mean of duplicate determinations.

(Table 1).

Up to a concentration of $0.025 \mathrm{mg}$ membrane protein/tube, TSH binding to rat fat membranes linearly increased along with the increase of protein concentra-

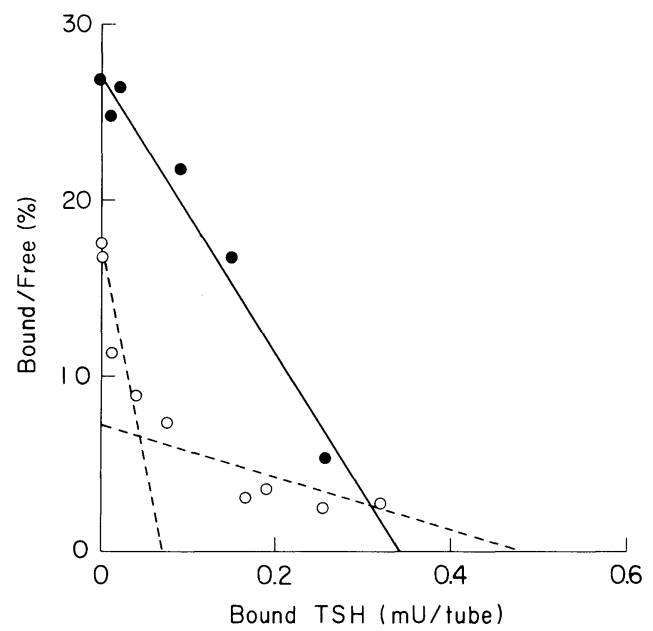

Fig. 4. Scatchard plot obtained from the data of Fig. 3. The concentration of TSH was calculated based on a molecular weight of 28,000 and a biological activity of $40 \mathrm{IU} / \mathrm{mg}$ for highly purified TSH. Rat fat membranes $(\bullet,-)$, human thyroid membranes $(0, \cdots)$. 
TABLE 2. Affinity constants and binding capacity of TSH receptors on rat fat and human thyroid membranes

\begin{tabular}{lccc} 
& $n$ & $\mathrm{~K}_{\mathrm{a}}\left(\times 10^{8} \mathrm{M}^{-1}\right)$ & $\mathrm{B}_{\max }\left(\times 10^{-9} \mathrm{~mole} / \mathrm{mg}\right.$ prot $)$ \\
\hline Rat fat & 5 & $2.6 \pm 0.8$ & $31.2 \pm 3.7$ \\
Human thyroid & 4 & $9.3 \pm 2.8^{* *}$ & $1.2 \pm 0.2^{* *}$ \\
& & $1.2 \pm 0.5^{*}$ & $8.1 \pm 3.4^{* *}$ \\
\hline
\end{tabular}

Each value was mean \pm s.D.

${ }^{*} p<0.05,{ }^{* *} p<0.01$ against values of rat fat membranes.

The molecular concentration of TSH was calculated based on a molecular weight of 28,000 and a biological activity of $40 \mathrm{IU} / \mathrm{mg}$ for highly purified TSH.

tions. As shown in Fig. 3, the binding to rat fat membranes was inhibited by unlabeled TSH in a dose-dependent manner. Conventional Scatchard analysis of this result gave a linear relationship and indicated the presence of a single class of high affinity TSH binding sites on rat fat membranes (Fig. 4). Table 2 shows the binding characteristics of rat fat and human thyroid membranes. Rat fat membranes possessed a lower affinity constant $(\mathrm{Ka})$ of $2.6 \times 10^{8} \mathrm{M}^{-1}$ and larger binding capacity per mg membrane protein $\left(31.2 \times 10^{-9}\right.$ mole $)$ than a high affinity binding site of human thyroid membranes $\left(9.3 \times 10^{8} \mathrm{M}^{-1}\right.$ and $1.2 \times 10^{-9}$ mole), although the yield of human thyroid membrane fraction from $1 \mathrm{~g}$ wet tissue was 10 times greater than that of rat fat membrane fraction.

Graves' IgG inhibited TSH binding to rat fat membranes. A good correlation was observed between TBII index obtained with these two membrane preparations (Fig. 5). Normal IgG markedly reduced TSH binding to rat fat

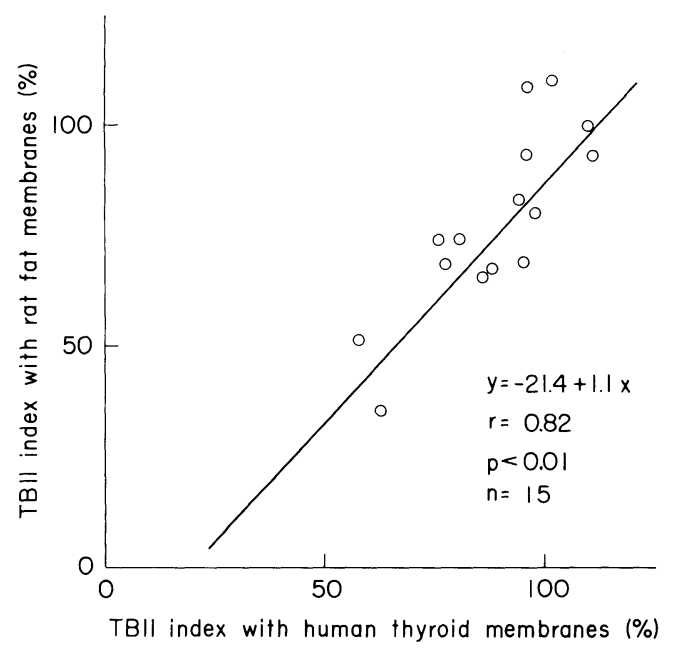

Fig. 5. Correlation of TBII index measured with rat fat and human thyroid membranes. 
membranes (specific binding: 5 to $7 \%$ ) but slightly inhibited the binding to human thyroid membranes (specific binding; 17 to $20 \%$ ).

\section{Discussion}

Specific binding sites for TSH have been shown to exist on the membranes prepared from rat fat tissues. TSH binding to rat fat membranes was noticeably rapid and unstable at $37^{\circ} \mathrm{C}$, unlike the binding to human thyroid membranes. This result was also different from those on TSH binding to guinea pig fat membranes prepared with an identical differential centrifugation process (Teng et al. 1975 ; Kishihara et al. 1979a).

The concentration of $50 \mathrm{mM}$ of $\mathrm{NaCl}$ significantly inhibited the binding to rat fat membranes whereas the same concentration of $\mathrm{NaCl}$ did not inhibit TSH binding to human thyroid membranes. Gill et al. (1978a, b) reported that TSH binding to guinea pig and human fat membranes was considerably reduced under such conditions. These results may suggest that TSH binding to fat membranes is highly sensitive to the presence of $\mathrm{NaCl}$. At present it is not clear whether the decrease in TSH binding to rat fat membranes observed with prolonged incubation after the addition of labeled $\mathrm{TSH}$ at $37^{\circ} \mathrm{C}$ and the presence of $\mathrm{NaCl}$ was due to factors such as the release of receptors from the membranes or changes in the receptor environment leading to altered kinetic characteristics. Triton X100 solubilized guinea pig fat membranes showed the same susceptibility to temperature (Kishihara et al. 1981), and in the present study the preincubation of rat fat membranes at $37^{\circ} \mathrm{C}$ for $45 \mathrm{~min}$ did not reduce $\mathrm{TSH}$ binding to rat fat membranes. These results probably suggest that the receptors in rat fat tissue are more susceptible to changes in the receptor environment than those in human thyroid gland. Susceptibility to these changes of TSH receptors on rat fat membranes may be a cause for the difficulty in determining TSH receptors on rat fat membranes.

TSH binding to rat fat membranes was not affected by the treatment with DTT or diamide, although Ozawa et al. (1979) and Koizumi et al. (1982) reported that $\mathrm{SH}$ reducing reagents decreased TSH binding to thyroid TSH receptors. Recent reports suggested that TSH receptors in human and porcine thyroid gland contained two subunits linked by a disulfide bridge(s) (Koizumi et al. 1982 ; Islam and Farid 1985; Kajita et al. 1985) and these reagents are thought to change these structures. Kajita et al. (1985) also reported that TSH receptors on guinea pig fat membranes were composed of two subunits. These findings may suggest some structural differences of TSH receptors on rat fat membranes from those on human thyroid membranes (Eggo and Burrow 1982).

The conventional Scatchard plots obtained from the displacement data showed a single class of high affinity binding site, whereas high and low affinity binding sites were present in human thyroid membranes as previously reported (Manley et al. 1974 ; Marshall et al. 1977 ; Powell-Jones et al. 1980 ; Pekonen and 
Weintraub 1980 ; Manley and Bourke 1981). As for guinea pig fat membranes a single class of binding sites (Gill et al. 1978a, 1980; Kishihara et al. 1981) or two binding sites (Kishihara et al. 1979a; Trokoudes et al. 1979; Leoffler et al. 1983) for TSH were reported. The reasons for this discrepancy were not clear. The impurity of labeled TSH was thought to be responsible. Kishihara et al. (1981) reported that a single class of binding site for TSH could be observed in guinea pig fat membranes using highly purified labeled bTSH although with relatively crude labeled bTSH two binding sites were detected. On the other hand, Loeffler et al. (1983) reported two binding sites for TSH using highly purified TSH. Other reports suggested that ionic strength of incubation buffer affected TSH binding to thyroid membranes (Powell-Jones et al. 1980; Pekonen and Weintraub 1980). In the present study we used the same labeled bTSH and incubation buffer to determine the TSH receptors on rat fat membranes, so a single class of binding sites was thought to be specific to rat fat membranes. The value of $\mathrm{Ka}$ of rat fat membranes was lower than that of high affinity site of human thyroid membranes, although the values of guinea pig fat membranes were reported to be similar to that of human thyroid membranes (Endo et al. 1981; Loeffler et al. 1983).

Immunoglobulins from patients with Graves' disease inhibited TSH binding to rat fat membranes as well as that to human thyroid membranes, although normal IgG significantly reduced TSH binding to rat fat membranes. TBII index obtained with these two membrane preparations were significantly correlated. These results suggest that TRAb crossreacts with TSH receptors on rat fat membranes. A significant correlation between the inhibition activities of Graves' IgG on TSH binding to guinea pig fat and human or porcine thyroid membranes was reported (Kishihara et al. 1979b; Parkes et al. 1985). From these findings it is conceivable that TRAb is not species specific as reported by Davies (1981) and Strakosch et al. (1982).

In conclusion, TSH has been shown to bind to rat fat membranes. The properties of TSH binding to rat fat membranes were not identical to those of TSH binding to human thyroid membranes. TRAb detected in sera of patients with Graves' disease crossreacted with TSH receptors in rat fat tissue.

\section{References}

1) Baker, J.R., Lukes, Y.G., Smallridge, R.C., Berger, M. \& Burman, K.D. (1983) Partial characterization and clinical correlation of circulating human immunoglobulins directed against thyrotrophin binding sites in guinea pig. J. clin. Invest., 72, 1487-1497.

2) Davies, T.F. (1981) Autoantibodies to the human thyrotropin receptor are not species specific. J. clin. Endocr., 52, 426-430.

3) Davies, T.F., Teng, C.S., McLachlan, S.M., Smith, B.R. \& Hall, R. (1978) Thyrotropin receptors in adipose tissue, retroorbital tissue and lymphocytes. Molec. cell. Endocr., 9, 303-310. 
4) Eggo, M.C. \& Burrow, G.N. (1982) Isolation of TSH receptor proteins by photoaffinity labeling. Clin. Res., 30, 490A. (abstract)

5) Endo, K., Amir, S.M. \& Ingbar, S. (1981) Development and evaluation of a method for the partial purification of immunoglobulins specific for Graves' disease. $J$. clin. Endocr., 52, 1113-1123.

6) Gill, D.L., Marshall, N.J. \& Ekins, R.P. (1978a) Binding of thyrotropin to receptors in fat tissue. Molec. cell. Endocr., 10, 89-102.

7) Gill, D.L., Marshall, N.J. \& Ekins, R.P. (1978b) Characterization of thyrotropin binding to specific receptors in human fat tissue. Molec. cell. Endocr., 12, 41-51.

8) Gill, D.L., Marshall, N.J. \& Ekins, R.P. (1980) Effects of immunoglobulins upon the interaction of thyrotropin with receptors in human fat tissue. Endocrinology, 107, 1813-1819.

9) Islam, M.N. \& Farid, N.R. (1985) Structure of the porcine thyrotropin receptor : A 200 kilodalton glycoprotein heterocomplex. Experimentia, 41, 18-23.

10) Kajita, Y., Rickards, C.R., Buckland, P.R., Howells, R.D. \& Smith, B.R. (1985) Analysis of thyrotropin receptors by photoaffinity labeling. Orientation of receptor subunits in the cell membrane. Biochem. J., 227, 413-420.

11) Kishihara, M., Nakao, Y., Baba, Y., Ohgo, S., Matsukura, S., Fuzita, T. \& Kuma, K. (1979a). Effects of alpha-and beta-adrenergic blockers on binding of thyrotrophin to fat cell membranes. Acta endocr., 90, 240-248.

12) Kishihara, M., Nakao, Y., Baba, Y., Matsukura, S. Kuma, K. \& Fuzita, T. (1979b) Interaction between thyroid stimulating immunoglobulins and thyrotropin receptors in fat cell membranes. J. clin. Endocr., 49, 706-711.

13) Kishihara, M., Nakao, Y., Baba, Y., Kobayashi, N., Matsukura, S., Kanji, K. \& Fuzita, T. (1981) Interaction between thyrotropin (TSH) binding inhibitor immunoglobulins (TBII) and soluble TSH receptors in fat cell. J clin. Endocr., 52, 665-670.

14) Koizumi, Y., Zakarija, M. \& McKenzie, J.M. (1982) Solubilization, purification, and partial characterization of thyrotropin receptor from bovine and human thyroid glands. Endocrinology, 110, 1381-1391.

15) Loeffler, M., Zakarija, M. \& McKenzie, J.M. (1983) Comparisons of different assays for the thyroid-stimulating antibody of Graves' disease. J. clin. Endocr., 57, 603-608.

16) Lowry, O.H., Rosebrough, N.J., Farr, A.L. \& Randall, R.J. (1951) Protein measurement with the folin phenol reagent. J. biol. Chem., 193, 265-275.

17) Manley, S.W. \& Bourke, J.R. (1981) Receptor heterogeneity in the human thyroid: Differences between thyrotropin binding sites in membrane and nuclear fraction. $J$. Endocr., 91, 163-173.

18) Manley, S.W., Bourke, J.R. \& Hawker, R.W. (1974) The thyrotrophin receptor in guinea pig thyroid homogenate: General properties. J. Endocr., 61, 419-436.

19) Marshall, N.J., Von Borcke, S., Florin-Christensen, A. \& Ekins, R.P. (1977) Propranolol increase binding of thyrotropin to thyroid membranes. Nature (Lond.), 268, 58-60.

20) Ozawa, Y., Chopra, I.J., Solomon, D.H. \& Smith, F. (1979) The role of sulfhydryl groups in thyrotropin binding and adenylate cyclase activities of thyroid plasma membranes. Endocrinology, 105, 1221-1225.

21) Parkes, A.B., Kajita, Y., Buckland, P.R., Howells, R.D., Rickards, C.R., Creagh, F.M. \& Smith, B.R. (1985) Immunoprecipitation of TSH-TSH receptor complexes. Clin. Endocr., 22, 511-520.

22) Pekonen, F. \& Weintraub, B.D. (1980) Salt-induced exposure of high affinity thyrotropin receptors on human and porcine thyroid membranes. J. biol. Chem., 255, 8121-8127.

23) Powell-Jones, C.H.J., Thomas, C.G., Jr. \& Naufeh, S.N. (1980) Thyrotropin recepor in normal human thyroid. $J$. biol. Chem., 255, 4001-4010.

24) Smith, B.R. \& Hall, R. (1974) Thyroid-stimulating immunoglobulins in Graves' 
disease. Lancet, 2, 427-431.

25) Smith, B.R., Rickards, C.R., Jones, E.D., Kajita, Y., Buckland, P.R., Creagh, F.M., Howells, R.D., Hashim, F., Parkes, A.B. \& Petersen, V.B. (1985) The thyrotropin receptor and its role in Graves' disease. J. endocr. Invest., 8, 175-182.

26) Strakosch, C.R., Joyner, D., Manley, S.W. \& Wall, J.R. (1982) The species specificity of TSH receptor binding antibodies as measured by radioreceptor assay. Clin. Endocr., 17, 173-179.

27) Tao, T. \& Kriss, J.P. (1982) Membrane-binding antibodies in patients with Graves' disease and other autoimmune diseases. J. clin. Endocr., 55, 935-940.

28) Teng, C.S., Smith, B.R., Anderson, J. \& Hall, R. (1975) Comparison of thyrotrophin receptors in membranes prepared from fat and thyroid tissue. Biochem. biophys. Res. Commun., 66, 836-841.

29) Trokoudes, K.M., Sugenoya, A., Hazani, E., Row, V.V. \& Volpé, R. (1979) Thyroidstimulating hormone (TSH) bindinbg to extrathyroidal human tissues: TSH and thyroid-stimulating immunoglobulin effects on adenosine $3^{\prime}, 5^{\prime}$-monophosphate in testicular and adrenal tissues. J. clin. Endocr., 48, 919-923. 